\title{
EVALUASI IMPLEMENTASI ASESMEN KINERJA PADA PEMBELAJARAN KETERAMPILAN LAS BERORIENTASIKAN PRODUK KRIYA LAS TERALIS DI SMK
}

\author{
Ilham $^{1}$, Wahid Munawar ${ }^{2}$, Sriyono $^{3}$ \\ Departemen Pendidikan Teknik Mesin \\ Universitas Pendidikan Indonesia \\ J1. Dr. Setiabudhi No. 207 Bandung 40154 \\ id.ilham44@gmail.com
}

\begin{abstract}
ABSTRAK
Sekolah Menengah Kejuruan memiliki banyak tujuan, salah satu diantaranya adalah menyiapkan peserta didik agar menjadi manusia produktif, mampu bekerja mandiri, mengisi lowongan pekerjaan yang ada sebagai tenaga kerja tingkat menengah sesuai dengan kompetensi dalam program keahlian yang dipilihnya. Salah satu yang mempengaruhi kurang optimalnya tujuan dari SMK belum terlaksana keterampilan las berorientasikan produk di SMK. Tujuan yang ingin dicapai dalam penelitian ini adalah untuk mendapatkan gambaran mengenai hasil evaluasi implementasi assesmen kinerja pada pembelajaran las yang berorientasikan produk untuk peserta didik SMK Negeri. Metode yang digunakan penelitian evaluatif dengan model evaluasi stake. Desain penelitian yang digunakan dalam penelitian ini adalah single subject research. Pengambilan dan pengolahan data difokuskan untuk melihat prilaku subjek. Hasil penelitian menunjukkan bahwa peserta didik telah melakukan pratikum las secara baik dengan waktu yang cukup.
\end{abstract}

Kata kunci: assesmen kinerja, berorientasi produk, implementasi, las listrik, kriya.

\section{PENDAHULUAN}

Undang-Undang No. 20 Tahun 2003 tentang Sistem Pendidikan Nasional, Bab II Pasal 3 menyatakan bahwa: pendidikan nasional berfungsi mengembangkan kemampuan serta membentuk watak dan peradaban bangsa yang bermartabat dalam rangka mencerdaskan kehidupan bangsa, bertujuan untuk mengembangkan potensi peserta didik agar menjadi manusia yang beriman dan bertakwa kepada Tuhan Yang Maha Esa, berakhlak mulia, sehat, berilmu, cakap, kreatif, mandiri, menjadi warga negara yang demokratis secara bertanggung jawab. Undang-undang tersebut menekankan pada kualitas sumber daya manusia, yang dalam hal ini peserta didik diharapkan melalui pendidikan, membentuk atau menghasilkan sumber daya manusia yang berkualitas dan bisa mandiri. Sumber daya manusia bisa mandiri jika memiliki suatu keterampilan yang menghasilkan pendapatan (Abidin, 2009).

Sekolah Menengah Kejuruan (SMK) merupakan salah satu jenjang pendidikan yang merupakan bagian dari sistem pendidikan nasional yang bertujuan yaitu mampu menciptakan lulusan yang mempunyai keterampilan dan mampu bersaing di dunia kerja (Salvia, J. dan Ysseldyke, 2010). Hal tersebut dapat terwujud, dengan SMK harus berinovasi menjadi lebih

\footnotetext{
${ }^{1}$ Mahasiswa Departemen Pendidikan Teknik Mesin FPTK UPI

2 Dosen Departemen Pendidikan Teknik Mesin FPTK UPI

${ }^{3}$ Dosen Departemen Pendidikan Teknik Mesin FPTK UPI
} 
baik, yang tertuang dalam UU No. 20 Tahun 2003 Pasal 15 yaitu: pendidikan kejuruan merupakan pendidikan menengah yang mempersiapkan peserta belajar terutama untuk bekerja dalam bidang tertentu.

Tujuan pendidikan menengah kejuruan adalah meningkatkan keimanan dan ketakwaan peserta didik kepada Tuhan Yang Maha Esa; mengembangkan potensi peserta didik agar menjadi warga Negara yang berakhlak mulia, sehat, berilmu, cakap, kreatif, mandiri, demokratis dan bertanggung jawab; mengembangkan potensi peserta didik agar memiliki wawasan kebangsaan, memahami dan menghargai keanekaragaman budaya bangsa Indonesia; dan mengembangkan potensi peserta didik agar memiliki kepedulian terhadap lingkungan hidup dengan secara aktif turut memelihara dan melestarikan lingkungan hidup, serta memanfaatkan sumber daya alam dengan efektif dan efisien.

Tujuan khusus pendidikan menengah kejuruan adalah menyiapkan peserta didik agar menjadi manusia produktif, mampu bekerja mandiri, mengisi lowongan pekerjaan yang ada sebagai tenaga kerja tingkat menengah sesuai dengan kompetensi dalam program keahlian yang dipilihnya. Menyiapkan peserta didik agar mampu memilih karir, ulet dan gigih dalam berkompetensi, beradaptasi di lingkungan kerja dan mengembangkan sikap profesional dalam bidang keahlian yang diminatinya. Membekali peserta didik dengan ilmu pengetahuan, teknologi dan seni agar mampu mengembangkan diri dikemudian hari baik secara mandiri maupun melalui jenjang pendidikan yang lebih tinggi. Membekali peserta didik dengan kompetensi yang sesuai dengan program keahlian yang dipilih. Sekolah menengah kejuruan adalah pendidikan pada jenjang menengah yang mengutamakan pengembangan kemampuan peserta didik untuk melaksanakan jenis pekerjaan tertentu (Sukardi, 2011).

Keterampilan bisa dibentuk melalui SMK, yang bertujuan menciptakan lulusan menjadi sumber daya manusia yang terampil, dapat bersaing di dunia kerja serta berkualitas. Semua dapat direalisasikan dengan memberikan pembelajaran yang baik dan bekal pengetahuan dan keterampilan kompetensi kejuruan sesuai dengan bidangnya masing-masing (Arikunto, 2009). Kegiatan pembelajaran membuat prakarya pengelasan merupakan salah satu cabang ilmu dasar teknik yang harus dikuasai peserta didik di SMK. Kenyataan dilapangan peserta didik belum melakukan pembelajaran keterampilan las yang berorientasikan produk. Mata pelajaran kejuruan terdiri atas beberapa mata pelajaran yang bertujuan untuk menunjang pembentukan kompetensi kejuruan dan pengembangan kemampuan menyesuaikan diri dalam bidang keahliannya. Keterampilan las termasuk kedalam bidang keterampilan otomotif yang harus dikuasai oleh peserta didik program keahlian otomotif (Dwidjamiko, 2008). 
Kondisi ini tidak sesuai dengan tujuan pendidikan karena peserta didik perlu memperluas keahliannya sebagai pelajar yang harus berkompetensi di dunia kejuruan. Pendidik professional harus memiliki standar penilaian yang baik, salah satunya diterapkan pada evaluasi implementasi asesmen keterampilan membuat prakarya produk pengelasan (Rusman, 2012). Tidak menerapkan asesmen kinerja yang baik membuat peserta didik tidak terampil dalam bidangnya, sehingga sulit bersaing di dunia kerja (Basuki dan Haryanto, 2014).

\section{METODE PENELITIAN}

Metode penelitian ini adalah penelitian evaluatif dengan model evaluasi Stake. Model ini menganalisis proses evaluasi yang dikemukakanya membawa dampak yang cukup besar dalam bidang ini dan meletakan dasar yang sederhana namun merupakan konsep yang cukup kuat untuk perkembangan yang lebih jauh dalam bidang evaluasi. Ada dua dasar kegiatan dalam evaluasi adalah description dan judgement, dan membedakan adanya tiga tahap yaitu: Antecedents (context), transaction (procces) dan outcomes (output). Desain penelitian yang digunakan dalam penelitian ini adalah single subject research. Penelitian subjek tunggal yaitu metode yang bertujuan untuk memperoleh data yang diperlukan dengan melihat hasil ada tidaknya pengaruh perubahan yang terjadi dari suatu perlakuan yang diberikan kepada subjek secara berulang-ulang dalam waktu tertentu.

\section{HASIL PENELITIAN}

Waktu pengerjaan produk las teralis yang dilakukan peserta didik dihitung oleh guru. Hasil perhitungan waktu pengerjaan las teralis meliputi: persiapan kerja, persiapan alat dan bahan, proses pengukuran bahan, proses bahan, proses pengelasan dan finishing (Putra, 2013). Pengerjaan diukur dari waktu standard yang diberikan (Lawshee dan Primardiana, 2013). Hasil penelitian menunjukkan bahwa siswa dapat menyelesaikan dengan waktu rata-rata 5353 detik sedangkan waktu standard adalah 5220 detik. Artinya siswa masih melakukan pratikum las listrik (teralis) masih di bawah waktu yang telah ditentukan. Nilai praktik dari peserta didik untuk pengelasan las teralis diperoleh rata-rata 81,6. Perhitungan ketercapaian pengerjaan las teralis yang dicapai peserta didik rata-rata 3,3. 
Tabel 1. Hasil ketercapaian penilaian kinerja pengerjaan las teralis

\begin{tabular}{lc}
\hline Komponen/Sub Komponen penilaian & Skor \\
\hline Persiapan Kerja & 3 \\
Proses (Sistematika dan Cara Kerja) & 3,5 \\
Sikap Kerja & 3,75 \\
Hasil Kerja & 3,25 \\
Waktu & 3 \\
Rata-rata & 3,3 \\
\hline
\end{tabular}

\section{PEMBAHASAN}

Nilai praktik pengerjaan teralis dengan nilai terendah adalah 80.7 diaman standar kelulusan mata pelajaran produktif adalah $>75$. Waktu yang dicapai oleh peserta didik dengan waktu terendah adalah 5329 detik dan peserta didik dengan waktu tertinggi adalah 5404 detik. Waktu untuk praktek yang disediakan oleh sekolah untuk praktik las teralis 2 (dua) jam ( $2 \mathrm{x}$ 45 menit), sehingga untuk satu orang peserta didik melakukan pratikum las teralis dibutuhkan waktu dua jam pelajaran ( 2 x 45 menit). Rincian proses dari awal hingga akhir dapat dibuat seperti berikut: rata-rata proses pengerjaan 90 menit, alokasi waktu pembelajaran yang harus disediakan untuk pembelajaran las teralis dibutuhkan 90 menit atau dua jam mata pelajaran. Ketercapaian pengerjaan las teralis yang diperoleh peserta didik dengan nilai tertinggi adalah 84.06 dan perolehan nilai terendah adalah 80.7.

\section{KESIMPULAN}

Hasil ketercapaian pengerjaan las teralis masih belum tercapai secara keseluruhan. Waktu terlama mencapai 90.06 menit dan waktu tercepat mencapai 88.81 menit. Waktu standar untuk pengerjaan las teralis adalah 87 menit. Hasil ketercapaian penilaian kinerja pengerjaan las teralis sudah memenuhi standard kelulusan. Pencapaian waktu dan perolehan hasil ketercapaian penilaian kinerja pada peserta didik menunjukkan bahwa peserta didik belum memenuhi syarat untuk pengerjaan las teralis.

\section{DAFTAR PUSTAKA}

Arikunto, S. (2009). Dasar-dasar Evaluasi Pendidikan. Jakarta: PT. Bumi Aksara.

Abidin, Y. (2009). Guru dan Pembelajaran Bermutu. Bandung: Rizqi Press.

Basuki, I dan Haryanto (2014). Asesmen Pembelajaran. Bandung: PT. Remaja Rosdarya 
Dwidjamiko, R. (2008). Teori Pengelasan Logam. Yogyakarta: Universitas Negeri Yogyakarta.

Lawshee dan Primardiana, (2013). Model Evaluasi Pembelajaran Berbasis Kaizen di Sekolah Menengah Atas. Jurnal Penelitian dan Evaluasi Pendidikan.

Putra, R. S. (2013). Desain Evaluasi Belajar Berbasis Kinerja. Jogjakarta: Diva Press.

Rusman. (2012). Model-Model Pembelajaran (Pengembangan Profesionalisme Guru). Depok: PT. Rajagrafindo Persada.

Salvia, J. dan Ysseldyke, J. (2010). Asessment (In Special and Inclusive Eduation), USA: Integra.

Sukardi. (2011). Evaluasi Pendidikan Prinsip dan Operasionalnya. Jakarta: Bumi Akasra. 